\title{
Nanoliposomes for Safe and Efficient Therapeutic mRNA Delivery: A Step Toward Nanotheranostics in Inflammatory and Cardiovascular Diseases as well as Cancer
}

\author{
Meike-Kristin Abraham, 2, Karlheinz Peter ${ }^{2,3}$, Tatjana Michel ${ }^{1}$, Hans Peter Wendel ${ }^{1}$, Stefanie Krajewski ${ }^{1 *}$, \\ Xiaowei Wang2, 3*凶 \\ 1. Department of Thoracic, Cardiac and Vascular Surgery, Clinical Research Laboratory, University Hospital Tübingen, Germany; \\ 2. Atherothrombosis and Vascular Biology, Baker Heart \& Diabetes Institute, Melbourne, Victoria, Australia; \\ 3. Department of Medicine, Monash University, Melbourne, Victoria, Australia. \\ * Equally contributing last authors \\ $\triangle$ Corresponding author: Dr. Xiaowei Wang, Atherothrombosis and Vascular Biology, Baker Heart and Diabetes Institute, 75 Commercial Road, Melbourne VIC \\ 3004 Fax: +61(3) 85321100 Tel: +61(3) 85321495 Email: xiaowei.wang@bakeridi.edu.au \\ (C) Ivyspring International Publisher. This is an open access article distributed under the terms of the Creative Commons Attribution (CC BY-NC) license \\ (https://creativecommons.org/licenses/by-nc/4.0/). See http://ivyspring.com/terms for full terms and conditions.
}

Received: 2017.02.02; Accepted: 2017.03.14; Published: 2017.04.05

\begin{abstract}
Rationale: Genetic therapy using modified mRNA for specific therapeutic protein expression for disease treatment and vaccination represents a new field of therapeutic and diagnostic medicine. Non-viral vectors transfection using biocompatible nanoliposomes enables safe and efficient delivery of therapeutic mRNA.

Objective: Generation of non-toxic, cell-compatible cationic nanoliposomes as nanotheranostic agents to successfully deliver therapeutic mRNA.

Methods and results: Cationic nanoliposomes (DC-Cholesterol/DOPE) were generated as transfection vehicles for either eGFP mRNA or the therapeutic anti-inflammatory, CD39 mRNA. We observed no toxicity using these nanoplexes and noted high cell viability after transfection. Nanoplexes for the transfection of eGFP mRNA showed an increase in fluorescence signals on microscopy as compared to the mRNA control after 24 hours in Chinese hamster ovary $(\mathrm{CHO})$ cells $(14.29 \pm 5.30$ vs. $1.49 \pm 0.54$; mean \pm SD respectively; $\mathrm{p}<0.001)$ and flow cytometry $(57.29 \pm 14.59$ vs $1.83 \pm 0.34 ; \%$ mean $\pm S D ; p<0.001)$. Nanoplexes for the transfection of CD39 mRNA showed increased CD39 expression in flow cytometry (45.64 \pm 15.3 vs. $3.94 \pm$ $0.45 ; \%$ mean $\pm S D ; p<0.001$ ) as compared to the mRNA control after 24 hours using $\mathrm{CHO}$ cells. We also demonstrated efficient transfection across several cell lines (CHO, HEK293, and A549), as well as long-term protein expression $(120 \mathrm{~h}$ and $168 \mathrm{~h})$ using these nanoplexes.

Conclusions: We have developed and tested non-toxic, safe, and efficient nanoliposome preparations for the delivery of therapeutic mRNA that hold promise for novel therapies in diseases such as inflammatory and cardiovascular diseases, as well as cancer. We have also demonstrated that this approach provides a reliable technology to deliver CD39 mRNA as an anti-inflammatory therapeutic for future nanotheranostics approaches.
\end{abstract}

Key words: anti-inflammatory, mRNA, nanoliposomes, therapeutics, transfection.

\section{Introduction}

Over the past years, modified messenger RNAs (mRNAs) have attracted major attention for therapeutic applications in inflammatory and cardiovascular diseases, in cancer, and for vaccination. ${ }^{1}$ The delivery of synthetic mRNA instead of deoxyribonucleic acid (DNA) to targeted cells for 
the expression of therapeutic proteins represents a new and exciting field of personalized medicine. ${ }^{2-4}$ Therapeutic mRNA offers higher safety through avoiding the need for genomic insertion, and is less immunogenic, and the therapeutic proteins are expressed under physiological conditions by the cells' own translational machinery.., 5

Furthermore, transient expression of the therapeutic proteins allows for a safe approach to be used in patients and is more desirable for some clinical disorders, and as a vaccination vector. ${ }^{4,5}$ Non-viral gene carriers, such as liposomes are cost efficient and highly suitable for non-toxic in vitro and in vivo delivery of exogenous genetic material and drugs into specific cell types. ${ }^{6}$

Liposomes are small, spherical amphiphilic vesicles consisting of a lipid bilayer, are biodegradable, biocompatible, non-pathogenic, and exhibit high agent-loading efficiency and great diversity in the lipid composition, as well as the possible surface modifications. 5,7,8 These liposomes are able to entrap hydrophobic agents within the bilayer, which shields the encapsulated agent or drug from degradation through, for example, nucleases. ${ }^{9}$ Cationic liposome-mediated transfection displays the most commonly used and most successfully applied method for the cellular transfection of DNA and siRNA. ${ }^{6,10-12}$ These charged liposomes consist of a cationic lipid and a neutral phospholipid, which can be loaded via electrostatic interactions with nucleic acids due to their negatively charged phosphate groups. ${ }^{13,14}$ These so-called lipoplexes can be taken up by the cells via endocytosis or endocytosis-like mechanisms. ${ }^{14,15}$ The first studies of liposome-based mRNA transfection using cationic DOTMA (1,2-di-O-octadecenyl-3-trimethylammonium

propane) / DOPE liposomes have been successful; however, the use of DOTMA is known to show cytotoxicity effects. ${ }^{2}$ Since transfecting mRNA has been attracting major interest for therapeutic purposes, there is a need to develop delivery systems, which possess high transfection efficiency and have no cytotoxic effects.

Here, we present a novel, non-toxic and effective approach for the transfection of mRNA using DC-Cholesterol/DOPE nanoliposomes (NLps). We demonstrate that this innovative approach can be used across several cell lines with good efficiency using the eGFP-encoding mRNA as a proof of concept model. We observed no effects on cell viability or hemocompatibility, highlighting the safety of these NLps. Using this exciting risk-free approach, we also established long term transfection of the anti-inflammatory/anti-thrombotic therapeutic CD39 mRNA.

\section{Material and Methods}

\section{Generation of synthetic mRNA}

The synthetic mRNAs (eGFP, CD39) were prepared as previously described.4,16 The vectors with coding sequences were amplified with a HotStar HiFidelity Polymerase Kit (Qiagen, Germany) using two primers, TTG GAC CCT CGT ACA GAA GCT AAT ACG as the forward primer (Ella Biotech, Germany) and $\mathrm{T}_{150}$ CTT CCT ACT CAG GCT TTA TTC AAA GAC CA as the reverse primer (Ella Biotech, Germany). DNA sequences were purified (Qiaquick PCR purification Kit, Qiagen, Germany), and in vitro transcription (IVT) was performed using a MEGAscript ${ }^{\circledR}$ T7 Kit (Ambion, Scotland), according to the manufacturer's instructions. The mRNA was modified using the $3^{\prime}-0-\mathrm{Me}-\mathrm{m}^{7} \mathrm{G}\left(5^{\prime}\right)$ ppp $\left(5^{\prime}\right) \mathrm{G}$ RNA cap structure analog (New England Biolabs, Germany), pseudouridine-5'-triphosphate (TriLink Biotech, U. S. A.), and 5-methylcytidine-5'triphosphate (TriLink Biotech, U. S. A.). Additionally, an RNase inhibitor (Themo Scientific, U. S. A.) was added. The IVT was incubated for $4 \mathrm{~h}$ at $37^{\circ} \mathrm{C}$.

Afterwards the mRNA was cleaned up with an RNeasy kit (Qiagen, Germany), and eluted in $40 \mu \mathrm{l}$ nuclease-free water. Next the dephosphorylation of mRNA was implemented with an Antarctic Phosphatase Kit (New England Biolabs, Germany), cleaned up and then eluted in the same amount of nuclease-free water. The concentration of mRNA was confirmed photometrically and the purity of mRNA with $1 \%$ agarose gel.

\section{Generation of nanoliposomes and nanoplexes}

DOPE (1,2-dioleoyl-sn-glycero-3-phosphoethanolamine) and DC-Cholesterol were purchased from Avanti Polar Lipids (U. S. A.) and used without further purification. The lyophilized lipids were dissolved in chloroform (Sigma-Aldrich, Germany) at $25 \mathrm{mg} / \mathrm{ml}$. Each lipid was further diluted to a convenient working solution of $3 \mathrm{mg} / \mathrm{ml}$. The formulation of 2:1 of DC-Cholesterol and DOPE was used, vortexed, and the solvent evaporated using $\mathrm{N}_{2}$ gas for several minutes. Residual solvent was removed by vacuum for at least $24 \mathrm{~h}$ via the dry film method. ${ }^{13,17}$

The obtained lipid film was hydrated with $1 \mathrm{ml}$ nuclease-free $\mathrm{H}_{2} \mathrm{O}$ by vortexing. After $10 \mathrm{~min}$ at room temperature, a cloudy suspension of multilamellar liposomes was sonicated until the solution cleared. The resulting liposomes were reduced in size and sterilized by extrusion about 21 times using an extruder (Avanti, U. S. A.) and a PC membrane $0.1 \mu \mathrm{m}$ (Avanti, U. S. A.). The resulting cationic nanoliposomes (NLps) were stored in glass vials at $4{ }^{\circ} \mathrm{C}$ before 
usage. Nanoplexes were formed via incubation of mRNA with NLps at room temperature for $20 \mathrm{~min}$, in either Opti-Mem ${ }^{\mathrm{TM}}$ (Gibco, Massachusetts, U. S. A.) or the desired cell media without fetal bovine serum (FBS).

\section{Characterization of nanoliposomes}

The size and size distribution of the generated NLps were measured at $25^{\circ} \mathrm{C}$ using a Malvern NanoZetaSizer (Malvern Instruments, U. K.) spectrometer (wavelength $\lambda=632.8 \mathrm{~nm}$ ). The volume-weighted Gaussian size distribution was fit to the autocorrelation functions, and particle size values were obtained.

\section{Transfection of CHO, HEK293, and A549 cells with generated nanoplexes}

For the transfection analysis, HEK293 (human embryonic kidney) cell line, $\mathrm{CHO}$ (chinese hamster ovary) cells, and A549 (adenocarcinomic human alveolar basal epithelial) cells were used. HEK293 and CHO cells were maintained in a DMEM (Gibco, U. S. A.), and A549 cells in an RPMI (Gibco, U. S. A.) in a humidified atmosphere of $5 \% \mathrm{CO}_{2}$ at $37^{\circ} \mathrm{C}$. Both media were supplemented with 10\% FBS, 1\% L-Glutamine, and 1\% penicillin and streptomycin.

One day prior to transfection, the respective cells were seeded with a density of 150,000 cells/well onto a 12-well plate (Corning Costar, U. S. A.). The nanoplexes as the transfection solution were prepared fresh as described above. The cells were washed twice with $1 \mathrm{ml}$ PBS (w/o $\mathrm{Ca}^{+} / \mathrm{Mg}^{+}$; PAA, Pasching, Austria), then the transfection was added to the cells and incubated for $24 \mathrm{~h}, 72 \mathrm{~h}, 120 \mathrm{~h}$, and $168 \mathrm{~h}$ at $37^{\circ} \mathrm{C}$. The incubators used were supplied with $5 \% \mathrm{CO}_{2}$ (Heraeus 6000; Thermo Fischer Scientific, Germany).

\section{XTT-viability assay}

Cell viability after transfection was analyzed using XTT (2,3-Bis-(2-Methoxy-4-Nitro-5-Sulfophenyl)-2H-Tetrazolium-5-Carboxanilide) (Sigma Aldrich, Germany) and PMS (Phenozine Methosulphate) (Sigma Aldrich, Germany). Actively respiring cells converted the water-soluble XTT into a water-soluble, orange-colored formazan product. The absorbance was measured at $475 \mathrm{~nm}$ after incubation with a microplate spectrophotometer (Benchmark Plus, BioRad, U. S. A.).

\section{Flow cytometry and fluorescence microscopy}

Flow cytometric analyses of the transfected HEK293, CHO, and A549 cells was performed to detect eGFP and CD39 expression. Therefore, $24 \mathrm{~h}, 72$ $\mathrm{h}, 120 \mathrm{~h}$, and $168 \mathrm{~h}$ after transfection, CD39-fluorescein isothiocyanate (FITC) antibody
(Abcam, U. K.: Clone A1) was used to detect CD39 expression using a FACS Calibur (BD Bioscience, U. S. A.). A total of 10,000 events were acquired in each sample. For the analysis of eGFP expression, no antibody was necessary.

The eGFP expression of $\mathrm{CHO}$ cells was additionally detected via fluorescence microscopy 24 $\mathrm{h}$ after transfection using a fluorescence microscope (IX2UCB, Olympus, Japan). The fluorescence intensity was analyzed by measuring the grey scale of the images using ImageJ.

\section{Hemocompatibility assay}

Blood-sampling procedures were approved by the Ethics Committee of the Alfred Hospital, Melbourne, Australia. Blood was collected from healthy volunteers who provided informed consent in accordance with the Declaration of Helsinki. $1 \mathrm{ml}$ citrated blood was incubated with $2.5 \mu \mathrm{l}$ NLPs, $0.5 \mu \mathrm{g}$ eGFP mRNA, nanoplexes $(2.5 \mu \mathrm{l}$ NLps and $0.5 \mu \mathrm{g}$ mRNA), or PBS as control at $37^{\circ} \mathrm{C}$ at $100 \mathrm{rpm}$. Complete blood counts were performed at different time points $(2 \mathrm{~h}$ and $4 \mathrm{~h})$ using a Hematology Analyzer (Sysmex xs-1000i, Japan).

\section{Statistics}

Unless otherwise specified, the data is represented as means with standard derivations (SD). All analysis for the two groups were performed using Student t-tests. All analyses containing more than two groups were analyzed with one-way ANOVA, comparing all groups with one another, corrected by post hoc Bonferroni analysis, and the corrected p-values are given. The statistical analyses were performed with the statistical software package GraphPad Prism (version 6.01, GraphPad Software, U. S. A.). Statistical significance was defined as $\mathrm{p}<0.05$.

\section{Results}

\section{Generation of eGFP mRNA and CD39 mRNA}

The eGFP and CD39 mRNA, and their purity, were analyzed on a 1\% TBE-agarose gel (Figure 1A). The purified CD39 mRNA (1533 bp) was visualized between the $1.5 \mathrm{~kb}$ and $2 \mathrm{~kb}$ markers, and the GFP mRNA (793 bp) was visualized just below the $1 \mathrm{~kb}$ marker.

\section{Characterization of cationic DC-Chol/DOPE nanoliposomes}

The generated NLps had a size distribution of $110.1 \pm 0.23 \mathrm{~nm}$ at day 1 (Figure $1 \mathrm{~B}$; mean $\pm \mathrm{SD}$ ) and $106.8 \pm 0.23 \mathrm{~nm}$ at day 30 . We observed no change in size after 30 days of storage at $4{ }^{\circ} \mathrm{C}$ (Figure 1C; NS). 

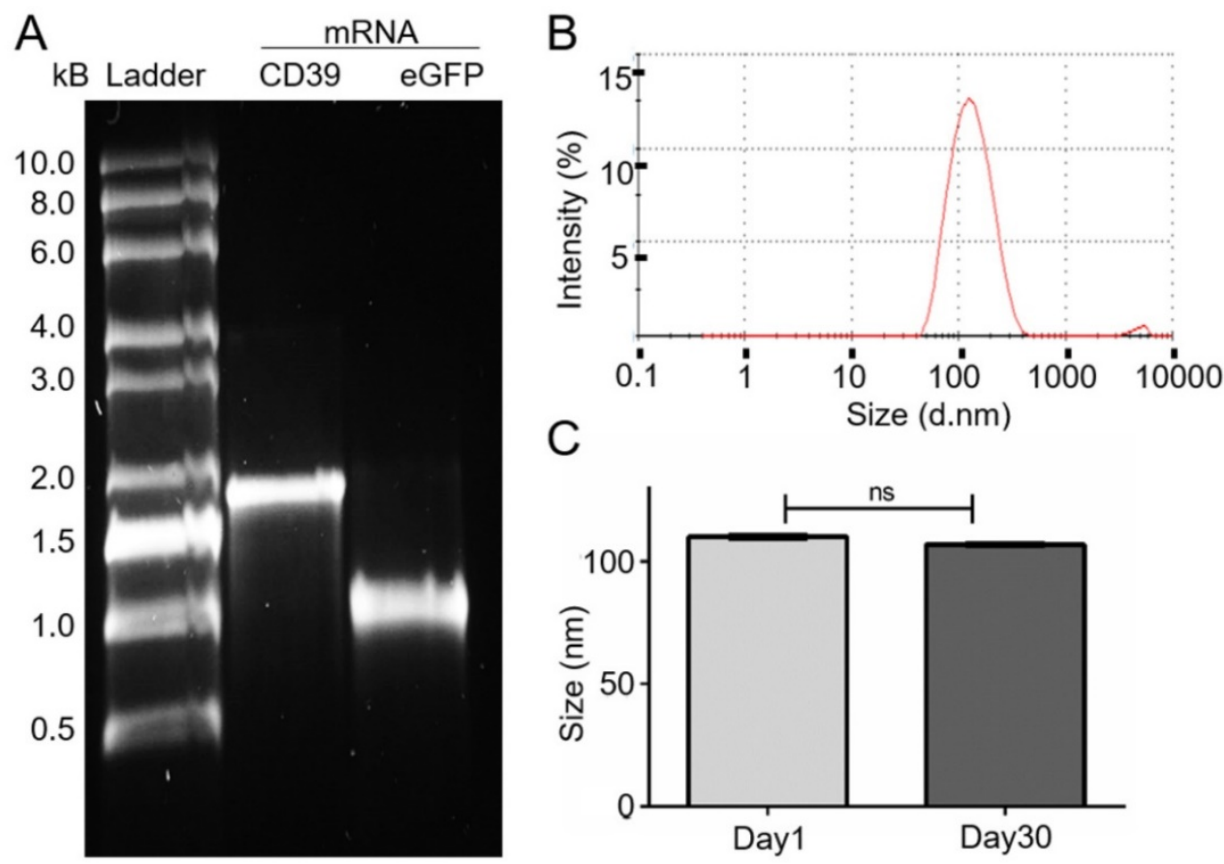

Figure 1. mRNA generation and size measurement of the DC-Cholesterol/DOPE nanoliposomes. (A) Electrophoresis with $1 \%$ agarose-TBE gel: CD39 mRNA (1533 bp). eGFP mRNA (993 bp) after purification and 0.5-10 kB RNA ladder. (B) Size distribution curve of the DC-Cholesterol/DOPE NLps 1 day after generation measured with a Zetazizer spectrometer exhibit an average of about $110 \mathrm{~nm}$. (C) Comparison of size distribution of liposomes 1 day and 30 days after generation showing no difference. The two groups were compared using Student t-tests (mean $\pm S D, n=5$ ).

\section{Evaluation of DC-Chol/DOPE nanoliposomes and nanoplexes for cell viability using $\mathrm{CHO}$ cells}

$\mathrm{CHO}$ cells were transfected with either $2.5 \mu \mathrm{l}$ of NLps, $0.5 \mu \mathrm{g}$ eGFP mRNA, the same concentration of nanoplexes, or PBS as control, and an XTT-viability assay was performed at $24 \mathrm{~h}, 48 \mathrm{~h}$, and $72 \mathrm{~h}$ post transfection (Figure 2). The transfection of liposomes showed no influence on the cell viability even $72 \mathrm{~h}$ after transfection with NLps, mRNA, or nanoplexes, as compared to the PBS control $(102.73 \pm 10.5$ vs 97.95 \pm 18.23 vs. $97.29 \pm 8.9$ vs. $99.99 \pm 2.3$; \% viability mean $\pm \mathrm{SD}$ respectively; NS). Similar results were observed at shorter time points of $24 \mathrm{~h}$ and $48 \mathrm{~h}$ (NS). Lower doses of NLps, mRNA concentrations, or nanoplexes also showed no change in cell viability (Supplemental Figure 1).

\section{Evaluation of transfection efficiency using nanoplexes with eGFP mRNA in vitro}

The transfection efficiency of the liposomes was investigated $24 \mathrm{~h}$ after transfection with eGFP nanoplexes in a fluorescence microscope (Figure 3). There were no fluorescence signals imaged on the controls (Supplemental Figure 2). There was increased fluorescence, which was confirmed with analysis of grey-scale intensity, for cells transfected with nanoplexes $(1 \mu \mathrm{l}$ NLps, $0.25 \mu \mathrm{g}$ mRNA), as compared to $1 \mu \mathrm{l}$ NLps, eGFP mRNA, or PBS control (16.86 \pm 47 vs. $2.01 \pm 1.22$ vs. $1.49 \pm 0.54$ vs. $1.58 \pm 0.64$; mean $\pm S D$ respectively; $\mathrm{AU} ; \mathrm{p}<0.001)$. This increase in the grey-scale intensity was also measured when increased amounts of NLps were used in the nanoplexes $(2.5 \mu \mathrm{l}$ NLps, $0.25 \mu \mathrm{g}$ mRNA), as compared to $2.5 \mu \mathrm{l}$ NLps as the control (14.29 \pm 5.30 vs. $1.87 \pm 0.46$; mean $\pm \mathrm{SD}$; $\mathrm{AU}$; $\mathrm{p}<0.001)$.

The measurement of \% eGFP expressed using flow cytometry showed an efficient transfection $24 \mathrm{~h}$ post incubation for nanoplexes $(1 \mu \mathrm{l}$ NLps, $0.25 \mu \mathrm{g}$ mRNA), as compared to $1 \mu \mathrm{l}$ NLps, eGFP mRNA, or PBS control $(43.57 \pm 20.59$ vs. $3.80 \pm 2.78$ vs. $1.82 \pm 1.34$ vs. $0.49 \pm 0.30 ; \%$ mean \pm SD respectively; Figure $4 \mathrm{~A}$; $\mathrm{p}<0.001)$. This increase in the \% eGFP expression was also measured when increased amounts of NLps were used in the nanoplexes ( $2.5 \mu \mathrm{l} \mathrm{NLps,} 0.25 \mu \mathrm{g}$ mRNA), as compared to $2.5 \mu \mathrm{l}$ NLps as control (57.29 \pm 14.70 vs. $10.56 \pm 5.48 ; \%$ mean \pm SD; Figure $4 \mathrm{~B} ; \mathrm{p}<0.001)$. The eGFP fluorescence measurement showed increased intensity with nanoplexes ( $1 \mu \mathrm{l}$ NLps, $0.25 \mu \mathrm{g}$ mRNA), as compared to $1 \mu \mathrm{l}$ NLps, eGFP mRNA, or PBS control (188.30 \pm 79.17 vs. $4.7 \pm 0.45$ vs. $2.30 \pm 0.20$ vs. $3.76 \pm 0.85$; mean $\pm \mathrm{SD}$ respectively; $\mathrm{AU} ; \mathrm{p}<0.001)$. Additionally, the same increase in fluorescence intensity was observed with higher amounts of nanoplexes $(2.5 \mu \mathrm{l}$ NLps, $0.25 \mu \mathrm{g}$ mRNA), as compared to $2.5 \mu \mathrm{l}$ NLps as control $(186.50 \pm 42.53 \mathrm{vs}$ $5.61 \pm 1.67$; mean \pm SD respectively; $A U ; p<0.001)$. Similar results were observed when Opti-MEM ${ }^{\mathrm{TM}}$ was used as the transfection medium (Supplemental Figure 3). 

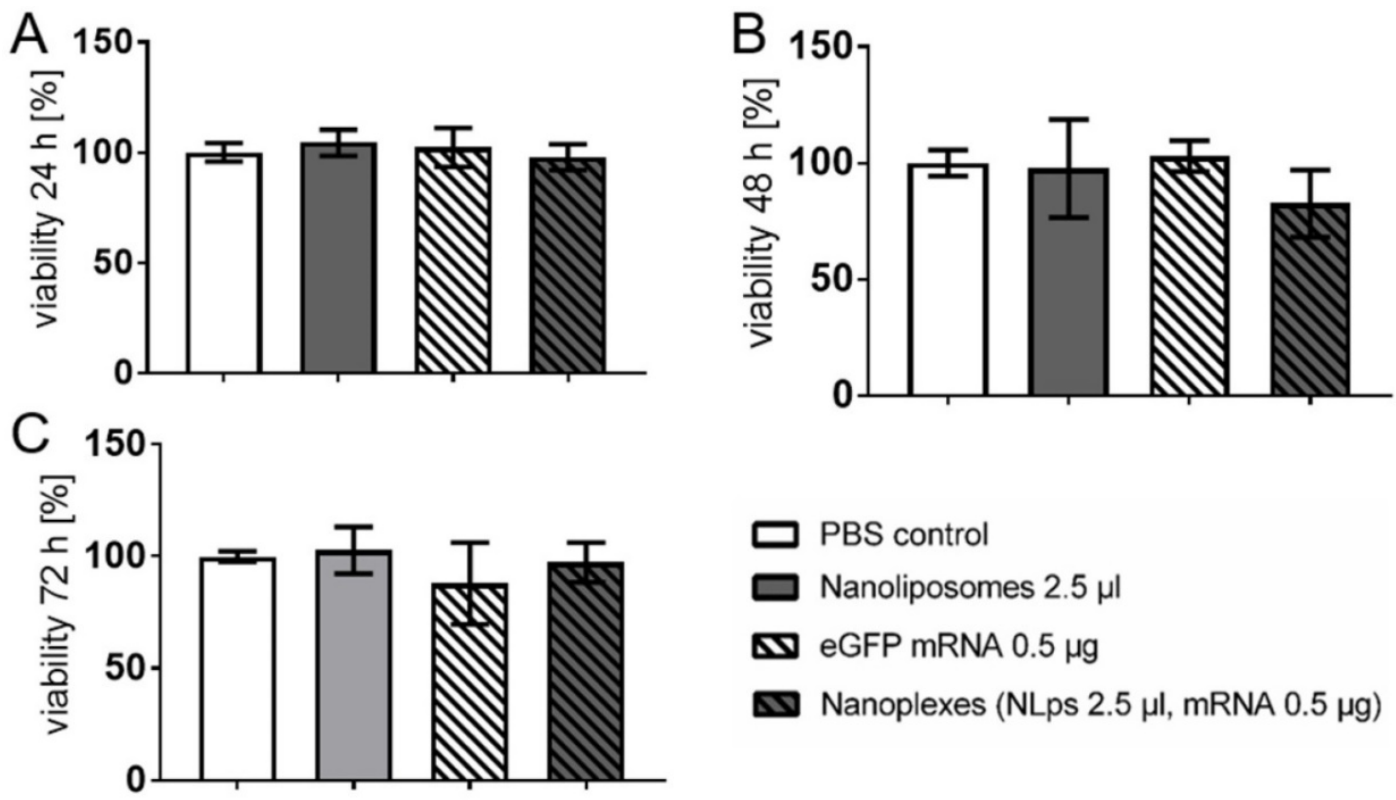

Figure 2. XTT-viability test showing no influence of the transfection of nanolipoplexes on $\mathrm{CHO}$ cells. $\mathrm{CHO}$ cells were transfected with eGFP mRNA and liposomes. The cell viability was analyzed $24 \mathrm{~h}(\mathbf{A}), 48 \mathrm{~h}(\mathbf{B})$, and $72 \mathrm{~h}$ (C) after transfection using XTT-tests and OD measurement, displaying no significant difference of the nanoplexes compared to the PBS, NLps, and mRNA controls. The PBS control was set to $100 \%$ and the different groups were compared by use of repeated ANOVA measures with Bonferroni post-tests (mean $\pm S D, n \geq 3$ ).
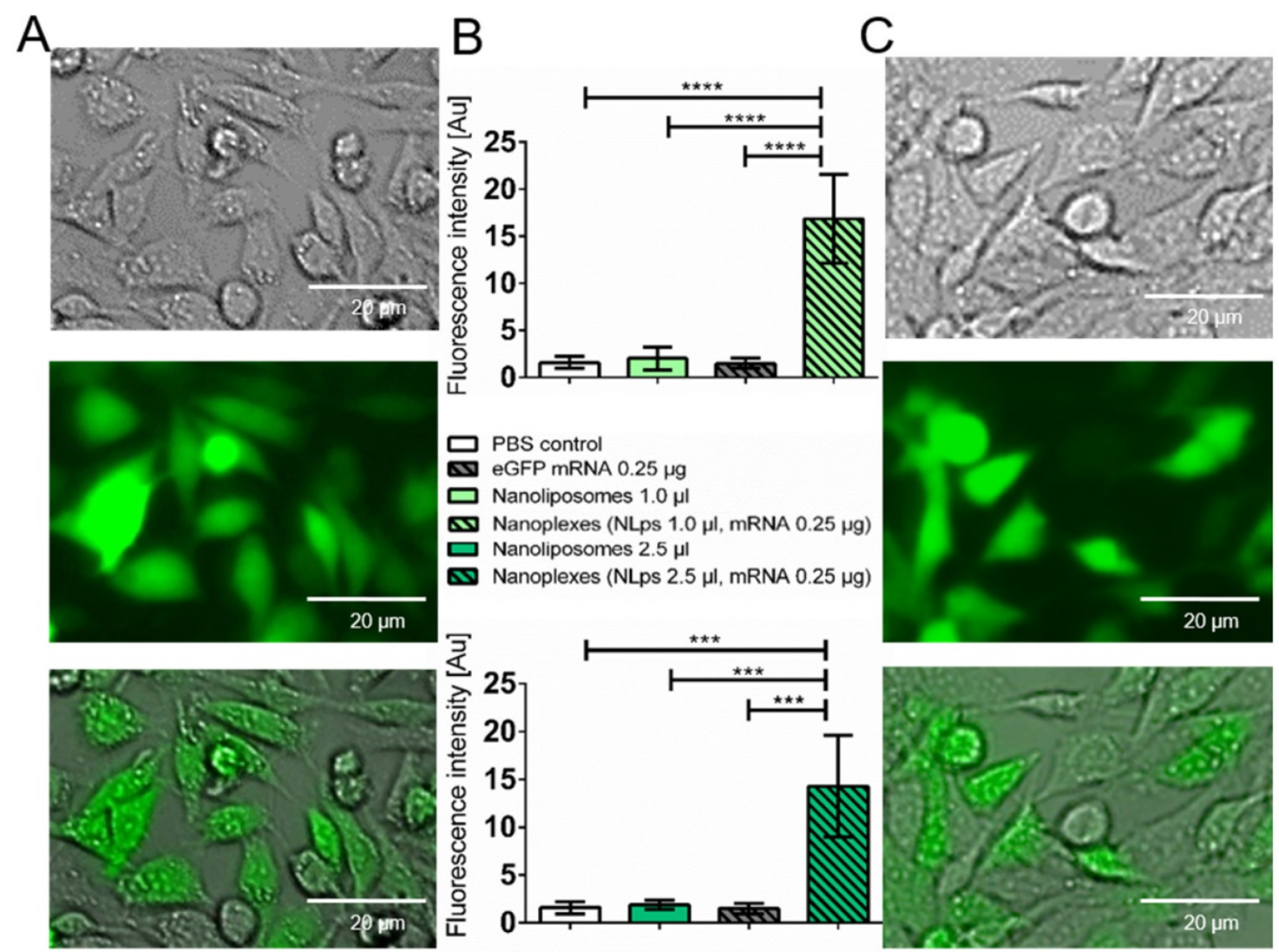

Figure 3. Microscope analysis demonstrates transfection efficiency of eGFP mRNA nanoplexes with media without FBS. CHO cells transfected with eGFP mRNA and different amounts of liposomes were analyzed $24 \mathrm{~h}$ after transfection under a fluorescent microscope. Representative images demonstrate a distinct expression with $1.0 \mu \mathrm{l}$ nanoplipoplexes $(\mathbf{A})$ and $2.5 \mu \mathrm{l}$ nanoplipoplexes $(\mathbf{C})$, supported by measurement of the fluorescence intensity via comparing the grey scale of fluorescent pictures (B). Bar charts were compared by use of repeated ANOVA measures with Bonferroni post-tests (mean \pm SD, *** $p>0.001$, **** $>0.001)$. 
A

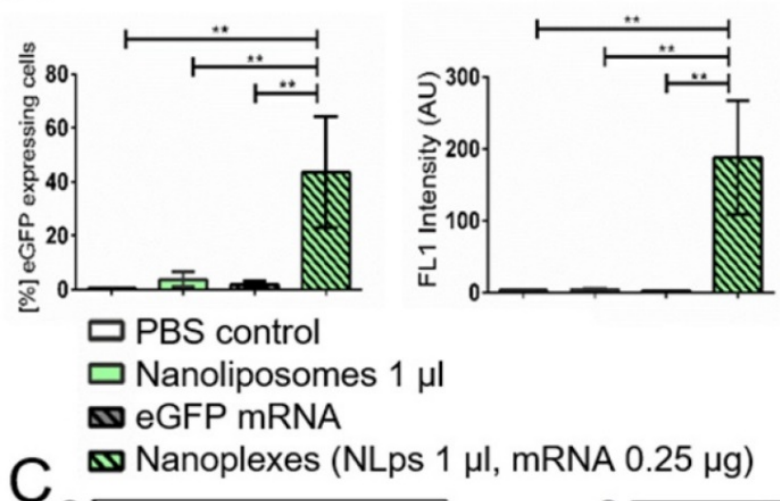

B

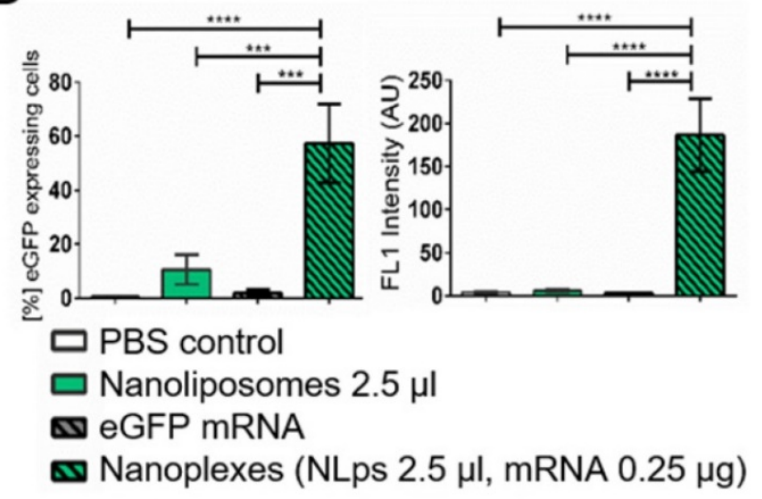

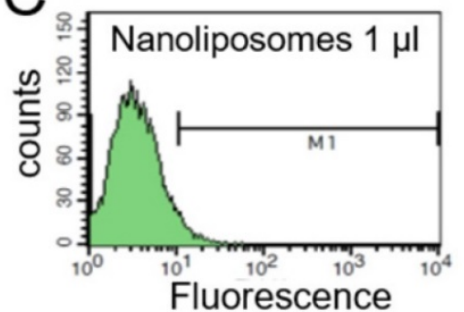
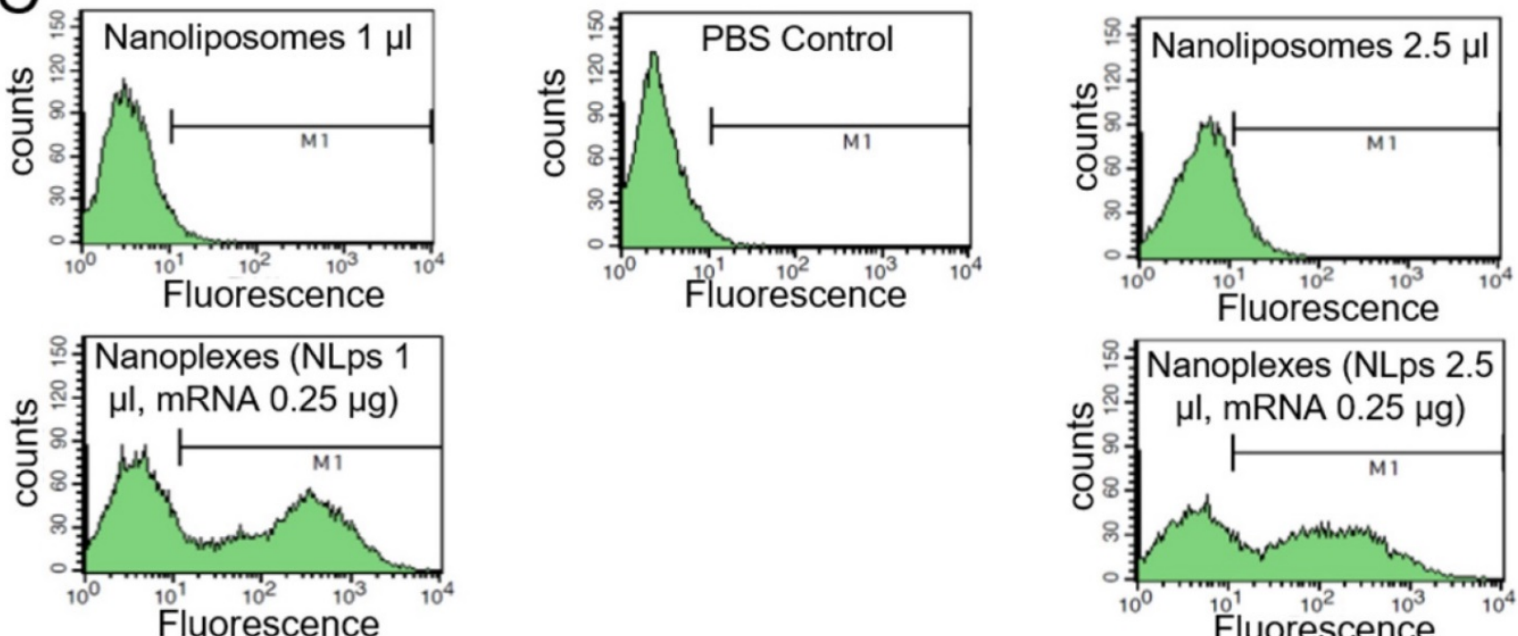

Fluorescence

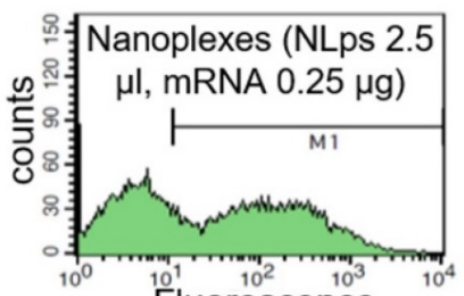

Figure 4. Flow cytometry demonstrating the transfection efficiency of eGFP mRNA nanoplexes in media without FBS in CHO cells. Significant transfection efficiency could be seen $24 \mathrm{~h}$ after transfection with eGFP mRNA using $1 \mu \mathrm{l}$ (A) and $2.5 \mu \mathrm{l}$ (B) nanoliposomes in flow cytometry. Bar graphs depict the $\%$ of protein expressing cells, as well as the median fluorescence intensity AU. The different groups were compared using repeated ANOVA measures with Bonferroni post-tests. (C) Representative fluorescence histograms are shown underneath the bar graphs (mean \pm SD, $* * * p<0.001, * * * * p>0.0001$ ).

\section{In vitro analysis of CD39 expression post transfection with nanoliposomes and therapeutic CD39 mRNA}

The short-term transfection efficiency of the therapeutic mRNA CD39 was evaluated using $\mathrm{CHO}$ cells the day prior to flow cytometry analysis (Figure 5). Using an anti-CD39 FITC-bound antibody, we showed successful CD39 protein expression $24 \mathrm{~h}$ post incubation with nanoplexes ( $1 \mu \mathrm{l}$ NLps, $0.25 \mu \mathrm{g}$ CD39 mRNA), as compared to $1 \mu \mathrm{l}$ NLps, CD39 mRNA, or PBS control $(36.82 \pm 17.74$ vs. $2.91 \pm 1.85$ vs. $3.9 \pm 0.45$ vs. $1.72 \pm 1.38$; \% mean \pm SD respectively; $A U ; \mathrm{p}<0.01$ ). This used higher doses of nanoplexes ( $2.5 \mu$ NLps, $0.25 \mu \mathrm{g}$ CD39 mRNA), as compared to $2.5 \mu \mathrm{l}$ NLps as control $(45.64 \pm 15.31$ vs. $9.11 \pm 4.28 ; \%$ mean \pm SD respectively; AU; $\mathrm{p}<0.001)$. Similar results were obtained using Opti-Mem ${ }^{\mathrm{TM}}$ as the transfection medium (Supplemental Figure 4).

Using an alternative cell line, we monitored for changes in cell morphology under the microscope. A higher dose of nanoplexes $(5 \mu \mathrm{l}$ NLps, $0.5 \mu \mathrm{g}$ CD39
mRNA) was added to HEK293 cells, and we observed that there was no influence on cell morphology at both $24 \mathrm{~h}$ and $72 \mathrm{~h}$ post transfection (Figure 6A). The $\%$ of HEK cells showing CD39 protein expression $72 \mathrm{~h}$ after transfection with nanoplexes was significantly higher than those with NLps only or PBS control (69.5 \pm 9.0 vs. $6.42 \pm 1.34$ vs. $0.61 \pm 0.10 ; \%$ mean $\pm \mathrm{SD}$ respectively; $\mathrm{p}<0.001$ ) (Figures $6 \mathrm{~B}$ and $6 \mathrm{C}$ ).

When performing a longer term transfection in another cell line, the A549 cells, elevated CD39 expression was observed $120 \mathrm{~h}$ (5 days) and $168 \mathrm{~h}$ (7 days) after transfection (Figure 7). A significant increase in CD39 expression was observed at $120 \mathrm{~h}$ post incubation with the nanoplexes, as compared to NLps, mRNA, or PBS control $(73.36 \pm 6.61$ vs. $8.75 \pm$ 0.08 vs. $14.54 \pm 4.41$ vs. $4.42 \pm 0.89 ; \%$ mean \pm SD respectively; $\mathrm{p}<0.001)$. Similarly, at $168 \mathrm{~h}$ transfection, nanoplexes resulted in significantly increased CD39 expression as compared to controls $(58.83 \pm 7.65$ vs. $8.27 \pm 4.92$ vs. $7.47 \pm 2.31$ vs. $5.69 \pm 0.43 ; \%$ mean $\pm S D$ respectively; $\mathrm{p}<0.001)$. 

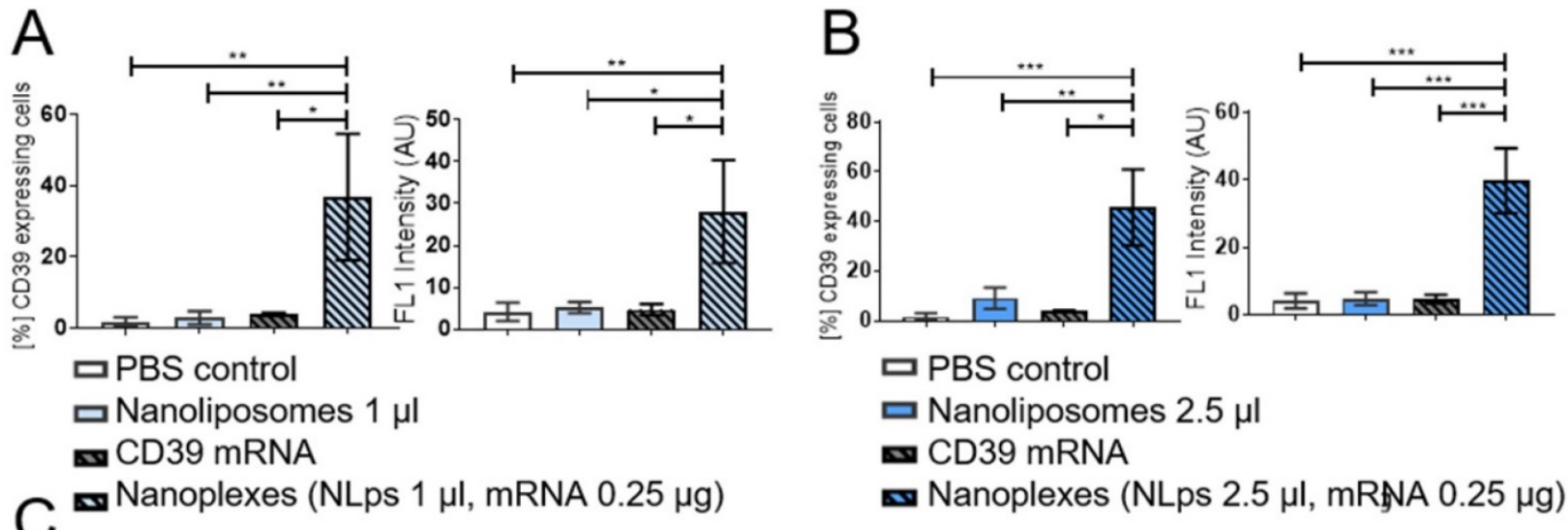

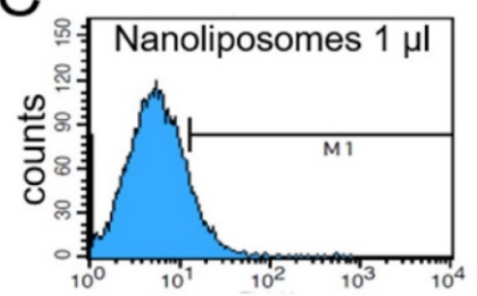

Fluorescence

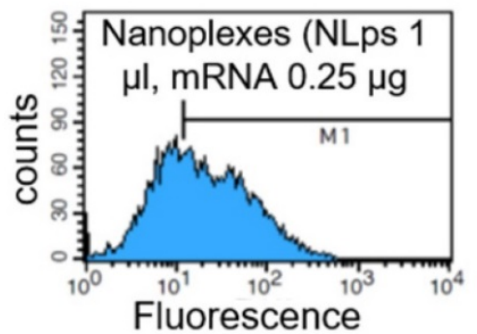

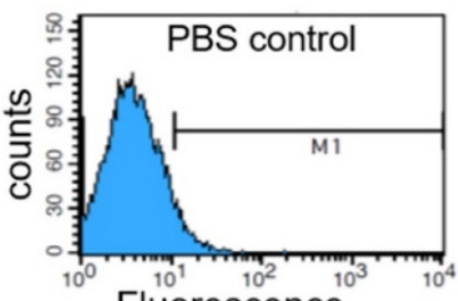

Fluorescence

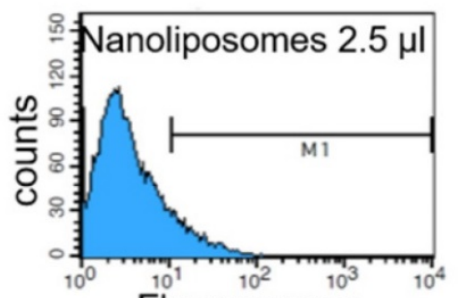

Fluorescence

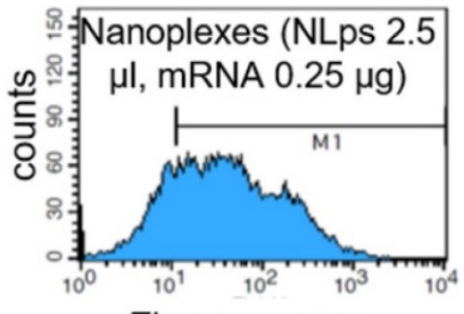

Fluorescence

Figure 5. Flow cytometry demonstrating the transfection efficiency of CD39 mRNA nanoplexes in media without FBS in CHO cells. Significant transfection efficiency could be seen $24 \mathrm{~h}$ after transfection with CD39 mRNA using $1 \mu \mathrm{l}(\mathbf{A})$ and $2.5 \mu \mathrm{l}(\mathbf{B})$ nanoliposomes using an anti-CD39-FITC antibody in flow cytometry. The bar graphs depict the \% of protein expressing cells, as well as the median fluorescence intensity AU. The different groups were compared using repeated ANOVA measures with Bonferroni post-tests. (C) Representative fluorescence histograms are shown underneath the bar graphs (mean \pm SD, **p $<0.01$, $* * * p>0.001)$.

\section{Investigation of hemocompatibility using nanoliposomes and nanoplexes}

Hemocompatibility was investigated using a hematology analyzer at $2 \mathrm{~h}$ and $4 \mathrm{~h}$ post incubation. Analyses of various cell types demonstrated no significant difference $2 \mathrm{~h}$ or $4 \mathrm{~h}$ post incubation with nanoplexes, NLps only, mRNA only, or PBS control (NS). Measurements were performed on white blood cells, red blood cells, hematocrit, platelets, lymphocytes, and monocytes (Figure 8; Supplemental Figure 5 and Supplemental Figure 6).

\section{Discussion}

We have demonstrated that NLps are suitable for the effective transfection of mRNA in vitro. In additional to the fact that they do not affect the viability of the cells, we have also demonstrated that they are hemocompatible. The nanoplexes, NLps, and loaded mRNA did not alter platelet function, and hence would not result in an increased risk of thrombus formation. Using three different cells lines as target cells, we observed protein expression of CD39 for up to 7 days post transfection even with small amounts of our nanoplexes. Moving forward, this proof of concept study will allow us to develop our NLps as a nanotheranostic technology to be used in the delivery of gene therapy in vivo.

The concept of the delivery of mRNA to be transcribed in vivo as a potential new drug class to deliver genetic information has attracted much interest as an alternative to plasmid DNA transfection. ${ }^{1,18,19}$ Since mRNA tranfection does not need entry to the nucleus, it does not integrate into the genome, thereby removing its risk of irreversible genomic modification and its transfection remains transient. 
A
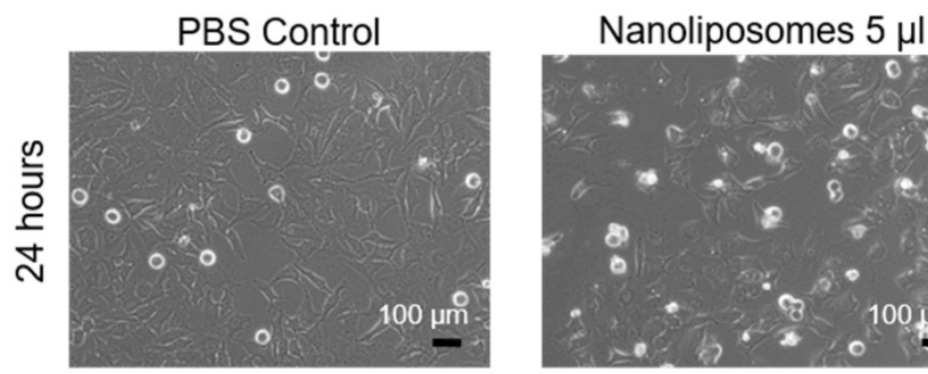

Nanoplexes (NLps $5 \mu$,

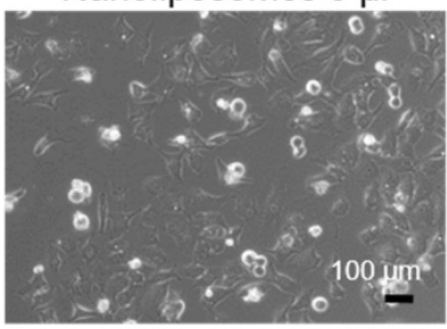

mRNA $0.5 \mu \mathrm{g})$
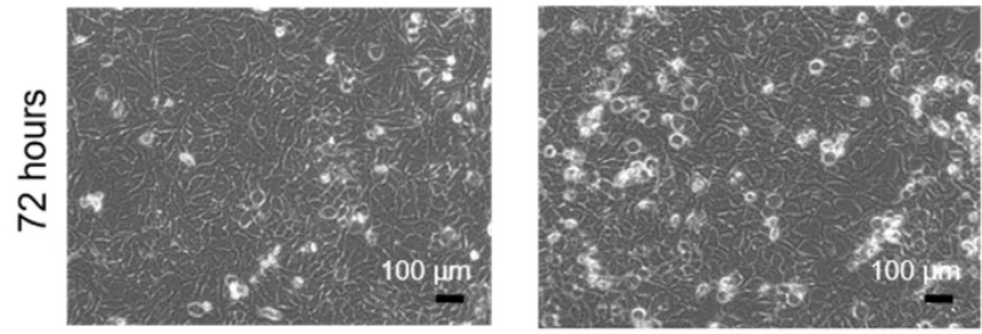

$\mathrm{B}$
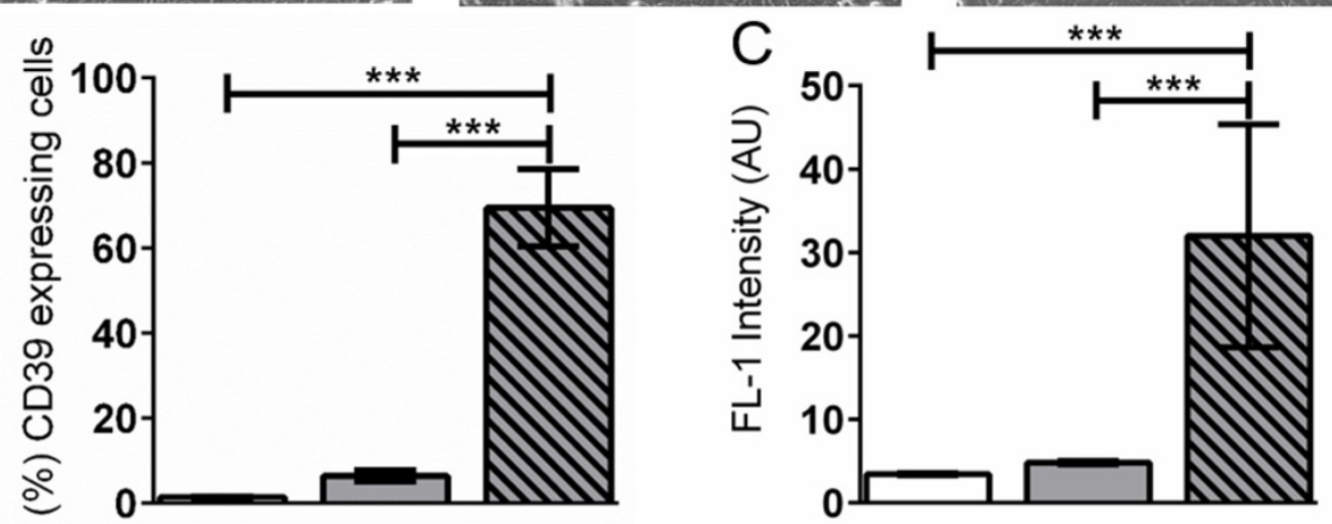

PBS Control $\square$ Nanoliposomes $5 \mu$

ه Nanoplexes (NLps $5 \mu \mathrm{l}$, mRNA $0.5 \mu \mathrm{g})$

Figure 6. CD39 mRNA nanoplexes demonstrating no influence on cell morphology, growth, or transfection efficiency in HEK293 cells $72 \mathrm{~h}$ after transfection in flow cytometry. (A) Representative microscope pictures show no influence on morphology or growth of $5 \mu$ l of CD39 mRNA nanoplexes after transfection on HEK293 cells after $24 \mathrm{~h}$ and $72 \mathrm{~h}$. The transfection efficiency (\%) (B) and mean fluorescence intensity (AU) (C) were evaluated additionally in flow cytometry $72 \mathrm{~h}$ after transfection using an anti-CD39-FITC antibody. The flow cytometry assay was analyzed using repeated ANOVA measures with Bonferroni post-tests (mean $\pm \mathrm{SD}, * * * \mathrm{p}>0.001)$.

A

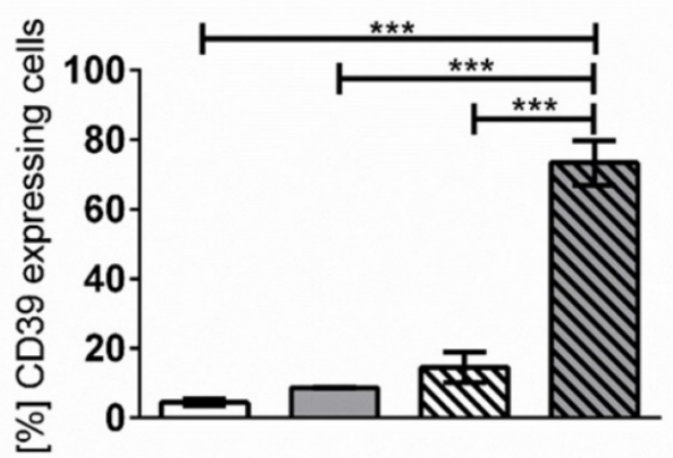

B

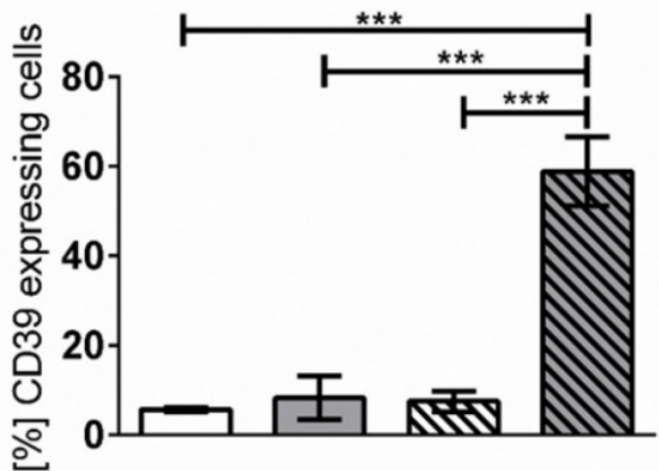

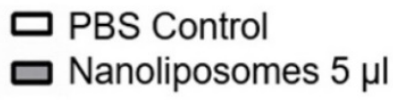

$\omega$ mRNA $0.5 \mu \mathrm{g}$

Nanoplexes (NLps $5 \mu \mathrm{l}$, mRNA $0.5 \mu \mathrm{g})$

Figure 7. CD39 mRNA nanoplexes show long-term transfection in A549 cells in flow cytometry. CD39 mRNA and $5 \mu$ l of nanoplexes were transfected in A549 cells. The efficiency was analyzed in flow cytometry $120 \mathrm{~h} \mathrm{(A)}$ and $168 \mathrm{~h} \mathrm{(B)} \mathrm{after} \mathrm{transfection} \mathrm{using} \mathrm{an} \mathrm{anti-CD39-FITC} \mathrm{antibody.} \mathrm{The} \mathrm{bar} \mathrm{graphs} \mathrm{depict} \mathrm{the}$ $\%$ of protein expressing cells. These assays were analyzed using repeated ANOVA measures with Bonferroni post-tests (mean \pm SD, $* * * p>0.001$ ). 

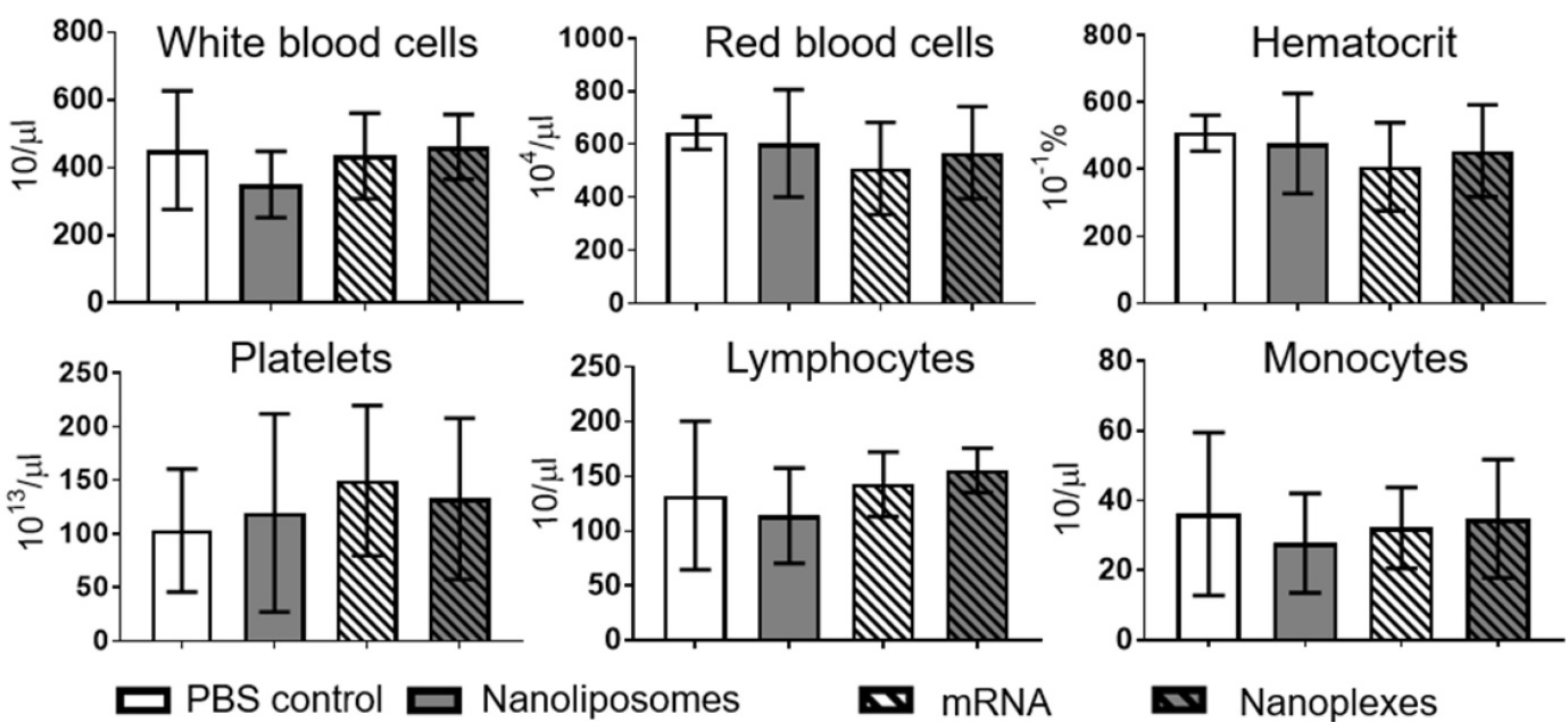

Figure 8: Hemocompatibility analysis demonstrates no effects of nanoliposomes or nanoplexes on human whole blood after $\mathbf{2}$ h. The complete blood count was analyzed after $2 \mathrm{~h}$ of incubation of whole human blood with nanoliposomes, mRNA, and nanoplexes at $37{ }^{\circ} \mathrm{C}$ for $4 \mathrm{~h}$ in total. No significant difference was seen in white blood cells, red blood cells, hematocrit, platelets, lymphocytes, or monocytes. The bar graphs were analyzed using repeated ANOVA measures with Bonferroni post-tests (mean $\pm \mathrm{SD}, \mathrm{n}=5$ ).

Many studies have already shown that, in comparison with DNA transfection, mRNA can be transfected and translated efficiently, and that mRNA-based therapy exhibits several advantages. 16,20,21 The cytoplasmic expression system utilized by mRNA enables quiescent or slower proliferating cells, including hepatocytes, vascular endothelial, and muscle cells, to be transfected. ${ }^{19}$ However, Barreau et al. observed that large amounts of free RNA molecules could become toxic and trigger stress responses of cells. ${ }^{22}$ Another concern is that the half-life of mRNA might be limited, as the mRNA might degrade after being added in vitro or in vivo, and so the ability for transfection and desired protein production might only last a few days. ${ }^{2,22}$ An elegant study by Rejman et al. demonstrated mRNA transfection of up to 9 days using $2 \mu \mathrm{g}$ of mRNA. ${ }^{23} \mathrm{In}$ our study, we have observed expression of CD39 for 7 days post incubation with our nanoplexes containing only $0.5 \mu \mathrm{g}$ of mRNA; therefore we have not observed any toxicity. As compared to other studies like that of Zohra et al., who used $3 \mu \mathrm{g}$ mRNA, we have shown a high transfection efficiency using as little as $0.25 \mu \mathrm{g}$ mRNA. ${ }^{24}$

Several methods have been used for the transfection of mRNA, mainly classified into viral and non-viral delivery.1,18,19 Viral delivery is more costly because the generation of such vectors for clinical use will likely be expensive. Electroporation as a method of transfection has been studied intensively, and used mainly for in vitro work. There have also been concerns in regard to the damage that electroporation may cause to the cells. Therefore, the ideal gene delivery carrier should guarantee a secure gene transport without exhibiting any immune response or toxicity, and should be able to be synthesized in a large scale. ${ }^{25}$ In order to diverge from the use of viral vectors, chemical transfections using non-viral carriers, such as cationic liposomes, polycationic polymers, nanoparticles and cationic dendrimers have been extensively studied. ${ }^{25,26}$ Of these, the use of cationic liposomes is the best established vehicle and it provides a cost-effective and safe method. ${ }^{6}$ The commercially available lipofectamine is widely used for DNA, mRNA, and siRNA transfection; however, it comes with cell toxicity. ${ }^{27}$ The protocol for incubation with lipofectamine is therefore usually less than 4 h. ${ }^{4}$

Our NLps and nanoplexes did not lyse the cells in blood, nor cause any thrombotic events. In addition, our in vitro assays showed good cell viability even after long-term incubations with NLps or nanoplexes. In addition, many studies have observed that Opti-MEM ${ }^{\mathrm{TM}}$ must be used for positive nucleic acid transfection because of interference with the nanocomplex formation. ${ }^{12,20}$ In our study, we have used Opti-MEM ${ }^{\mathrm{TM}}$ as our control, but have also successfully demonstrated equal efficiency in transfection using the cell lines' preferred media without FBS.

Our cationic NLps consist of the cationic lipid DC-Cholesterol and the neutral helper lipid DOPE. This combination has been presented in several transfection studies. ${ }^{15,28,29}$ The positively charged head group of DC-Cholesterol results in the delivery of genetic materials into various cell lines; the incorporation of cholesterol into liposomes has also 
been shown to prevent aggregation, improve serum stability, and enhance transfection efficiency. ${ }^{10,14,17}$ Neutral lipids like DOPE increase the rigidity and delivery efficiency, and to aid in the assembly of cationic liposomes. ${ }^{11,15,30}$

If the circulation half-life or the size of the NLps need to be prolonged, they can be stabilized using polyethylene glycol (PEG). The incorporation of PEG corona might protect them against degradation, and this modification may in turn enable a longer transfection and greater protein expression to be achieved. In addition to their transfection ability, there is great potential for the development of these NLps for co-delivery of other therapeutic drugs or imaging agents. ${ }^{19}$ In the field of cancer, where Zong et al. demonstrated stable and efficient delivery via $\mathrm{pH}$-sensitive polydopamine-coated liposomes loaded with the chemotherapeutic agent 5-fluorouracil (5-FU). ${ }^{31}$ Wang et al. presented a cationic PLGA-folate-coated PEG-liposome for targeted co-delivery of the drug doxorubicin, along with DNA gene therapy, in MDA-MB-231 tumor cells. ${ }^{32}$

The development of effective nanocarriers and the improvement of their delivery system play important roles in the detection of biomarkers and treatment of diseases. Within the past years, many have recognized that liposomal delivery of drugs and nucleic acids is one of the most interesting theranostic approaches for safe gene transfection and therapy.7,15,33 Efforts have been invested to increase the stability of liposomes, as well as superior encapsulation, greater biocompatibility, and higher loading efficiency for better biodistribution, enabling them to be employed as theranostic agents in clinical studies. ${ }^{24,29,34,35}$

The clinical translation of the described therapeutic approach is feasible. Several published studies have shown the clinical applicability of mRNA vaccination. ${ }^{36-39}$ Pollard et al. reported that mRNA encoding of the HIV gag antigen, complexed with DOTAP/DOPE liposomes, could be successfully delivered to DC cells for immunization. ${ }^{37}$ This approach also showed reduced innate immunity, compared to initial performances of DNA vaccines. In another promising study based on Novartis's proprietary adjuvant MF59 combined with the lipid DOTAP, a cationic emulsion was employed for the stimulation of the immune response via the antigen-specific $\mathrm{CD} 4^{+} \mathrm{T}$-cell response. ${ }^{40}$

\section{Perspective for the transfection of CD39 mRNA}

In our study, we have demonstrated the successful protein expression of CD39 in three different cell lines after mRNA transfection. This clearly demonstrates the potential for an anti-thrombotic and anti-inflammatory genetic therapy. CD39 is an ectonucleoside triphosphate diphosphohydrolase which degrades adenosine 5 -diphosphate (ADP), a major player in the platelet activation cascade, and therefore represents a promising anti-thrombotic strategy. ${ }^{41}$ In the vasculature, CD39 is normally expressed on the surface of endothelial cells, preventing platelets from activation and attachment to resting endothelium. Therefore, CD39 plays an important role in response to vascular injury and homeostasis, and plays an essential role in modulating vascular thrombosis and inflammation. ${ }^{42}$ In fact, several studies have shown the benefits of elevated CD39 levels in animal models of thrombosis, including myocardial infarction and stroke. ${ }^{42,43}$ In addition, based on the fact that NTPDase activity is substantively lost in the vascular system of injured or rejected grafts, Robson et al. described the potential of targeted expression of CD39 in transplantation-associated application and thrombosis. ${ }^{44}$ However, similar to current anti-thrombotic drugs, this therapy is associated with concentration-dependent bleeding complications. 45,46 To overcome this, Hohmann et al. also created an activated platelet-specific single-chain antibody fused with the CD39 protein and demonstrated the anti-thrombotic effects of this fusion construct in a carotid artery thrombosis model. ${ }^{47}$

Likewise, the use of our NLps for transfection of CD39 mRNA will allow the transmembrane protein to be expressed on the cell surface. The hydrolyzing effects of CD39 expressed on the cell will in turn prevent inflammation and also provide anti-platelet activity, both of which will hinder the development of atherosclerosis and thrombosis. ${ }^{43,44}$ The current proof of concept study will be the basis for further modification of our NLps for targeted therapeutic gene delivery and possible cell specific transfection to prevent platelet activation and inflammation. However, as is the case for nanotechnology in general, the clinical utility of our approach remains to be proven.

\section{Conclusion}

Recent developments in the field of liposomal delivery of therapeutic nucleic acids provide a wide range of applications and improved therapeutics. We have generated NLps using cationic DC-Cholesterol and DOPE for the delivery and transfection of therapeutic mRNA into three cell lines. We have observed no effects on cell viability or hemocompatibility. The finding that CD39 protein expression was evident for 7 days indicates that this non-viral gene delivery carrier could potentially be 
used for long term transfections in various areas of medical need. Such a nanotheranostic approach would be of particular interest for areas such as anti-inflammation, anti-thrombotic and anti-cancer therapy.

\section{Abbreviations}

CD39: ectonucleoside triphosphate diphosphohydrolase-1; CHO: Chinese hamster ovary; DC-Chol: 3B-[N-(N',N'-dimethylaminoethane)-carbamoyl]chole sterol; DMEM: (Dulbecco's Modified Eagle's medium); DOPE: 1,2-dioleoyl-sn-glycero-3-phosphoethanolamine; DOTMA: 1,2-di-O-octadecenyl-3trimethylammonium propane; eGFP: enhanced green fluorescence protein; FACS: fluorescence activated cell sorting; FBS: fetal bovine serum; HEK293: human embryonic kidney cells; mRNA: messenger ribonucleic acid; NLps: nanoliposomes; OD: optical density; PMS: phenozine methosulphate; siRNA: small interfering RNA; XTT: 2,3-Bis-(2-Methoxy4-Nitro-5-Sulfophenyl)-2H-Tetrazolium-5-Carboxanili de.

\section{Supplementary Material}

Supplementary figures.

http://www.ntno.org/v01p0154s1.pdf

\section{Acknowledgements}

The abstract graphic was generated using Servier Medical Art. We would like to thank Dr. Paul Ramsland for technical support and use of the Zetasizer (Malvern) at RMIT University, Melbourne.

\section{Funding Sources}

M-K. A. is supported by the German Research Association (Deutsche Forschungsgemeinschaft); K. P. is supported by a National Health and Medical Research Council Principal Research Fellowship; S. K. is supported by the Margarete von Wrangell-Habilitationsstipendium des Ministeriums für Wissenschaft, Forschung und Kunst Baden-Württemberg; X. W. is supported by a National Heart Foundation Postdoctoral Fellowship and the Paul Korner Innovation Award.

\section{Competing Interests}

The authors have declared that no competing interest exists.

\section{References}

1. Sahin U, Karikó K, Türeci Ö. mRNA-based therapeutics--developing a new class of drugs. Nat Rev Drug Discov. 2014;13:759-780.

2. Malone RW, Felgner PL, Verma IM. Cationic liposome-mediated RNA transfection. Proc Natl Acad Sci U S A. 1989;86:6077-6081.

3. Zohra FT, Chowdhury EH, Akaike T. High performance mRNA transfection through carbonate apatite-cationic liposome conjugates. Biomaterials. 2009:30:4006-4013
4. Avci-Adali M, Behring A, Keller T, Krajewski S, Schlensak C, Wendel HP. Optimized conditions for successful transfection of human endothelial cells with in vitro synthesized and modified mRNA for induction of protein expression. J Biol Eng. 2014;8:8.

5. Akbarzadeh A, Rezaei-Sadabady R, Davaran S, Joo SW, Zarghami N, Hanifehpour Y, Samiei M, Kouhi M, Nejati-Koshki K. Liposome: classification, preparation, and applications. Nanoscale Res Lett. 2013;8:102.

6. Yang S, Zheng Y, Chen J, Zhang Q, Zhao D, Han D, Chen X. Comprehensive study of cationic liposomes composed of DC-Chol and cholesterol with different mole ratios for gene transfection. Colloids Surf B Biointerfaces. 2013;101:6-13.

7. Ross PC, Hui SW. Lipoplex size is a major determinant of in vitro lipofection efficiency. Gene Ther. 1999;6:651-659.

8. Ryhänen SJ, Säily MJ, Paukku T, Borocci S, Mancini G, Holopainen JM, Kinnunen PKJ. Surface charge density determines the efficiency of cationic gemini surfactant based lipofection. Biophys J. 2003;84:578-587.

9. Xing H, Hwang K, Lu Y. Recent Developments of Liposomes as Nanocarriers for Theranostic Applications. Theranostics. 2016;6:1336-1352.

10. Bennett MJ, Nantz MH, Balasubramaniam RP, Gruenert DC, Malone RW. Cholesterol enhances cationic liposome-mediated DNA transfection of human respiratory epithelial cells. Biosci Rep. 1995;15:47-53.

11. Martin B, Sainlos M, Aissaoui A, Oudrhiri N, Hauchecorne M, Vigneron J-P, Lehn J-M, Lehn P. The design of cationic lipids for gene delivery. Curr Pharm Des. 2005;11:375-394.

12. Munye MM, Ravi J, Tagalakis AD, McCarthy D, Ryadnov MG, Hart SL. Role of liposome and peptide in the synergistic enhancement of transfection with a lipopolyplex vector. Sci Rep. 2015;5:9292

13. Son KK, Patel DH, Tkach D, Park A. Cationic liposome and plasmid DNA complexes formed in serum-free medium under optimum transfection condition are negatively charged. Biochim Biophys Acta. 2000;1466:11-15.

14. Shim G, Kim M-G, Park JY, Oh Y-K. Application of cationic liposomes for delivery of nucleic acids. Asian J Pharm Sci. 2013;8:72-80.

15. Lonez C, Vandenbranden M, Ruysschaert J-M. Cationic lipids activate intracellular signaling pathways. Adv Drug Deliv Rev. 2012;64:1749-1758.

16. Abraham M-K, Nolte A, Reus R, Behring A, Zengerle D, Avci-Adali M, Hohmann JD, Peter K, Schlensak C, Wendel HP, Krajewski S. In vitro Study of a Novel Stent Coating Using Modified CD39 Messenger RNA to Potentially Reduce Stent Angioplasty-Associated Complications. PloS One. 2015;10:e0138375.

17. Pozzi D, Marchini C, Cardarelli F, Amenitsch H, Garulli C, Bifone A, Caracciolo G. Transfection efficiency boost of cholesterol-containing lipoplexes. Biochim Biophys Acta. 2012;1818:2335-2343.

18. Tavernier G, Andries O, Demeester J, Sanders NN, De Smedt SC, Rejman J. mRNA as gene therapeutic: how to control protein expression. J Control Release Off I Control Release Soc. 2011;150:238-247.

19. Wang Y, Su H, Yang Y, Hu Y, Zhang L, Blancafort P, Huang L. Systemic Delivery of Modified mRNA Encoding Herpes Simplex Virus 1 Thymidine Kinase for Targeted Cancer Gene Therapy. Mol Ther. 2013;21:358-367.

20. Rolland A. Nuclear gene delivery: the Trojan horse approach. Expert Opin Drug Deliv. 2006;3:1-10.

21. Michel T, Kankura A, Salinas Medina ML, Kurz J, Behring A, Avci-Adali M, Nolte A, Schlensak C, Wendel HP, Krajewski S. In Vitro Evaluation of a Novel mRNA-Based Therapeutic Strategy for the Treatment of Patients Suffering from Alpha-1-Antitrypsin Deficiency. Nucleic Acid Ther. 2015;25:235-244.

22. Barreau C, Dutertre S, Paillard L, Osborne HB. Liposome-mediated RNA transfection should be used with caution. RNA. 2006;12:1790-1793.

23. Rejman J, Tavernier G, Bavarsad N, Demeester J, De Smedt SC. mRNA transfection of cervical carcinoma and mesenchymal stem cells mediated by cationic carriers. J Control Release Off I Control Release Soc. 2010;147:385-391.

24. Zohra FT, Maitani Y, Akaike T. mRNA delivery through fibronectin associated liposome-apatite particles: a new approach for enhanced mRNA transfection to mammalian cell. Biol Pharm Bull. 2012;35:111-115.

25. Ren X, Feng Y, Guo J, Wang H, Li Q, Yang J, Hao X, Lv J, Ma N, Li W. Surface modification and endothelialization of biomaterials as potential scaffolds for vascular tissue engineering applications. Chem Soc Rev. 2015;44:5680-5742.

26. Yang J, Feng Y, Zhang L. Biodegradable carrier/gene complexes to mediate the transfection and proliferation of human vascular endothelial cells. Polym Adv Technol. 2015;26:1370-1377.

27. Dalby B, Cates S, Harris A, Ohki EC, Tilkins ML, Price PJ, Ciccarone VC. Advanced transfection with Lipofectamine 2000 reagent: primary neurons, siRNA, and high-throughput applications. Methods. 2004;33:95-103.

28. Maitani $\mathrm{Y}$, Igarashi $\mathrm{S}$, Sato $\mathrm{M}$, Hattori $\mathrm{Y}$. Cationic liposome (DC-Chol/DOPE=1:2) and a modified ethanol injection method to prepare liposomes, increased gene expression. Int J Pharm. 2007;342:33-39.

29. Wasungu L, Hoekstra D. Cationic lipids, lipoplexes and intracellular delivery of genes. I Control Release Off I Control Release Soc. 2006;116:255-264.

30. Ramezani M, Khoshhamdam M, Dehshahri A, Malaekeh-Nikouei B. The influence of size, lipid composition and bilayer fluidity of cationic liposomes on the transfection efficiency of nanolipoplexes. Colloids Surf B Biointerfaces. 2009;72:1-5

31. Zong W, Hu Y, Su Y, Luo N, Zhang X, Li Q, Han X. Polydopamine-coated liposomes as $\mathrm{pH}$-sensitive anticancer drug carriers. I Microencapsul. 2016;33:257-262. 
32. Wang H, Zhao P, Su W, Wang S, Liao Z, Niu R, Chang J. PLGA/polymeric liposome for targeted drug and gene co-delivery. Biomaterials. 2010;31:8741-8748.

33. Ciani L, Ristori S, Salvati A, Calamai L, Martini G. DOTAP/DOPE and DC-Chol/DOPE lipoplexes for gene delivery: zeta potential measurements and electron spin resonance spectra. Biochim Biophys Acta. 2004;1664:70-79.

34. Feng L, Cheng L, Dong Z, Tao D, Barnhart TE, Cai W, Chen M, Liu Z Theranostic Liposomes with Hypoxia-Activated Prodrug to Effectively Destruct Hypoxic Tumors Post-Photodynamic Therapy. ACS Nano. 2016;

35. Caracciolo G, Callipo L, De Sanctis SC, Cavaliere C, Pozzi D, Laganà A. Surface adsorption of protein corona controls the cell internalization mechanism of DC-Chol-DOPE/DNA lipoplexes in serum. Biochim Biophys Acta. 2010;1798:536-543.

36. Brito LA, Chan $M$, Shaw CA, Hekele A, Carsillo $T$, Schaefer $M$, Archer Seubert A, Otten GR, Beard CW, Dey AK, Lilja A, Valiante NM, Mason PW, Mandl CW, Barnett SW, Dormitzer PR, Ulmer JB, Singh M, O'Hagan DT, Geall AJ. A cationic nanoemulsion for the delivery of next-generation RNA vaccines. Mol Ther J Am Soc Gene Ther. 2014;22:2118-2129.

37. Pollard C, Rejman J, De Haes W, Verrier B, Van Gulck E, Naessens T, De Smedt S, Bogaert P, Grooten J, Vanham G, De Koker S. Type I IFN counteracts the induction of antigen-specific immune responses by lipid-based delivery of mRNA vaccines. Mol Ther J Am Soc Gene Ther. 2013;21:251-259.

38. Schlake T, Thess A, Fotin-Mleczek M, Kallen K-J. Developing mRNA-vaccine technologies. RNA Biol. 2012;9:1319-1330.

39. Weiner DB. RNA-based vaccination: sending a strong message. Mol Ther J Am Soc Gene Ther. 2013;21:506-508.

40. O'Hagan DT. MF59 is a safe and potent vaccine adjuvant that enhances protection against influenza virus infection. Expert Rev Vaccines. 2007;6:699-710.

41. Knowles AF. The GDA1_CD39 superfamily: NTPDases with diverse functions. Purinergic Signal. 2011;7:21-45.

42. Kanthi YM, Sutton NR, Pinsky DJ. CD39: Interface between vascular thrombosis and inflammation. Curr Atheroscler Rep. 2014;16:425.

43. Marcus AJ, Broekman MJ, Drosopoulos JHF, Olson KE, Islam N, Pinsky DJ, Levi R. Role of CD39 (NTPDase-1) in thromboregulation, cerebroprotection, and cardioprotection. Semin Thromb Hemost. 2005;31:234-246.

44. Robson SC, Wu Y, Sun X, Knosalla C, Dwyer K, Enjyoji K. Ectonucleotidases of CD39 family modulate vascular inflammation and thrombosis in transplantation. Semin Thromb Hemost. 2005;31:217-233.

45. Charo IF, Taub R. Anti-inflammatory therapeutics for the treatment of atherosclerosis. Nat Rev Drug Discov. 2011;10:365-376.

46. Dwyer KM, Robson SC, Nandurkar HH, Campbell DJ, Gock H, Murray-Segal LJ, Fisicaro N, Mysore TB, Kaczmarek E, Cowan PJ, d'Apice AJF. Thromboregulatory manifestations in human CD39 transgenic mice and the implications for thrombotic disease and transplantation. I Clin Invest. 2004;113:1440-1446.

47. Hohmann JD, Wang X, Krajewski S, Selan C, Haller CA, Straub A, Chaikof EL, Nandurkar HH, Hagemeyer CE, Peter K. Delayed targeting of CD39 to activated platelet GPIIb/IIIa via a single-chain antibody: breaking the link between antithrombotic potency and bleeding? Blood. 2013;121:3067-3075. 